\title{
Mass Production Test of Solar Cells and Modules Made of 100\% UMG Silicon. 20.76\% Record Efficiency
}

\author{
Eduardo Forniés ${ }^{1, *}$, Bruno Ceccaroli ${ }^{2}$, Laura Méndez ${ }^{1}$, Alejandro Souto ${ }^{3}$, \\ Antonio Pérez Vázquez ${ }^{3}$, Timur Vlasenko ${ }^{3}$ and Joaquín Dieguez ${ }^{4}$ \\ 1 Aurinka PV Group, Marie Curie 19, Rivas-Vaciamadrid, 28521 Madrid, Spain; lmendez@aurinkapv.com \\ 2 Marche and Isosilicon AS, Rognelia 30, 4622-Kristiansand, Norway; br-c@online.no \\ 3 FerroSolar, C Ucrania 6, Puertollano, 13500 Ciudad Real, Spain; asouto@ferroglobe.com (A.S.); \\ anpervaz@ferroglobe.com (A.P.V.); tvlasenko@ferrosolar.com (T.V.) \\ 4 Ferroglobe, 15142 Arteixo-La Coruña, Spain; jdieguez@ferroglobe.com \\ * Correspondence: efornies@aurinkapv.com
}

Received: 2 April 2019; Accepted: 17 April 2019; Published: 19 April 2019

check for updates

\begin{abstract}
For more than 15 years FerroAtlantica (now Ferroglobe) has been developing a method of silicon purification to obtain Upgraded Metallurgical Grade Silicon (UMG-Si) for PV solar application without blending. After many improvements and optimizations, the final process has clearly demonstrated its validity in terms of quality and costs. In this paper the authors present new results stemming from a first mass-production campaign and a detailed description of the purification process that results in the tested UMG-Si. The subsequent steps in the value chain for the wafer, cell and module manufacturing are also described. Two independent companies, among the Tier-1 solar cells producers, were selected for the industrial test, each using a different solar cell technology: Al-BSF and black silicon + PERC. Cells and modules were manufactured in conventional production lines and their performances compared to those obtained with standard polysilicon wafers produced in the same lines and periods. Thus, for Al-BSF technology, the average efficiency of solar cells obtained with UMG-Si was $(18.4 \pm 0.4) \%$ compared to $18.49 \%$ obtained with polysilicon-made wafers. In the case of black silicon + PERC, the average efficiency obtained with UMG-Si was $(20.1 \pm 0.6) \%$, compared to $20.41 \%$ for polysilicon multicrystalline wafers.
\end{abstract}

Keywords: solar cells; UMG silicon; purification; PERC; black silicon

\section{Introduction}

Photovoltaics has for long clearly demonstrated its ability to be a competitive source of electricity. Measured in terms of Levelized Cost of Electricity (LCOE), photovoltaic power plants appear far more competitive than either fossil or other renewable energies (Figure 1).

To achieve this, many contributions have been necessary along the whole value chain combining cost reduction and increase of efficiency. Thanks to drastic cost reductions and massive capacity expansion over years, the silicon material which accounts for 20-24\% of the PV module cost (in Figure 2, sum of blue and green slices), contributes largely to keep crystalline silicon in the lead of PV technologies. The UMG-Si used in this test has incidence in the green slice (convers. Me-Si to Si-So) of Figure 2.

After years of development, FerroGlobe has decided, under the name of FerroSolar OpCo, to move to industrial scale for producing UMG silicon (UMG-Si) for solar applications. A new factory is currently being built in Puertollano (Spain) with a capacity of $3000 \mathrm{t} /$ year (Figure 3). This factory will deploy a process concept developed through many years while adding new recent improvements that will help to further reduce the cost and improve the quality. The aim of this factory of moderate output 
capacity is to become the basic unit and platform to further grow up to the Gigawatt level, and further decrease the cost through economy of scale.

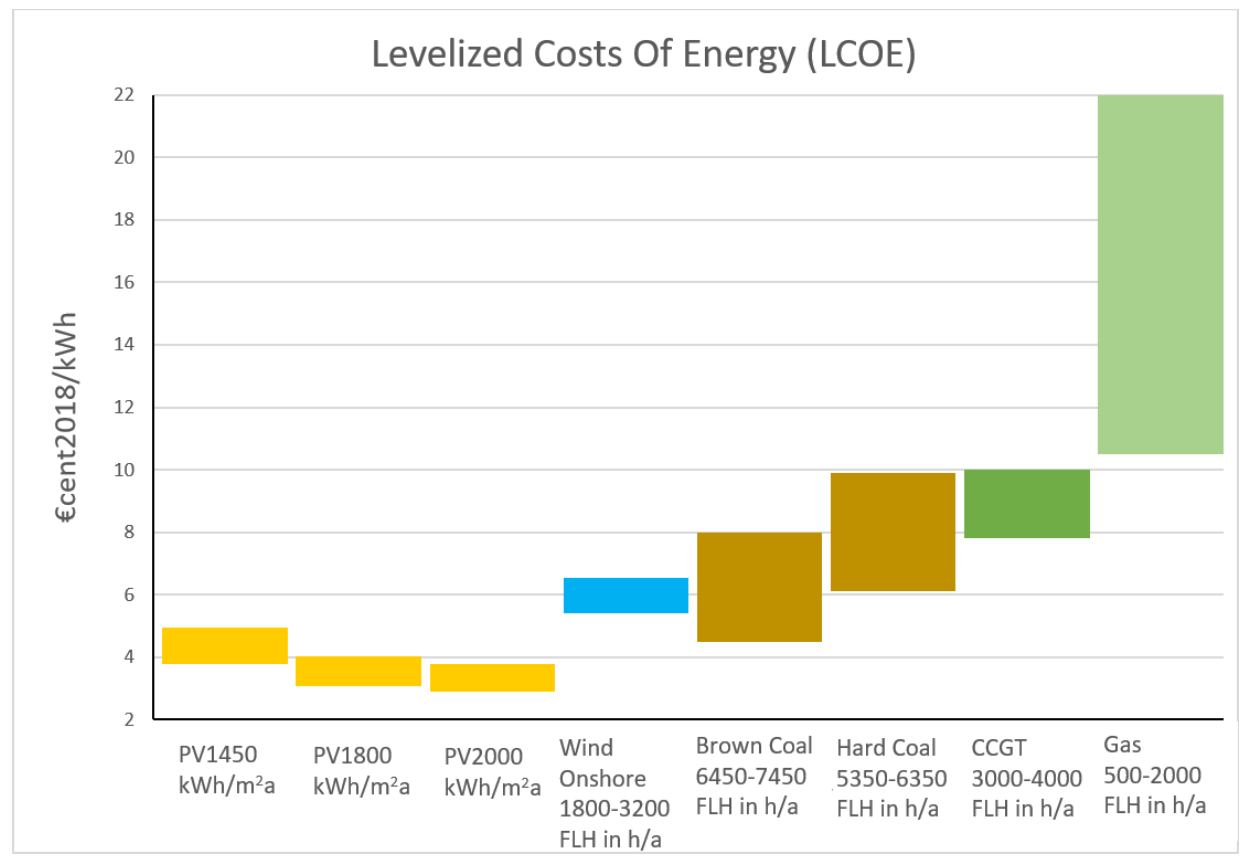

Figure 1. Levelized Costs of Electricity. Renewable Energy Technologies. March 2018. Fraunhofer ISE [1]. FLH in h/a refers to the annual full load hours per annum.

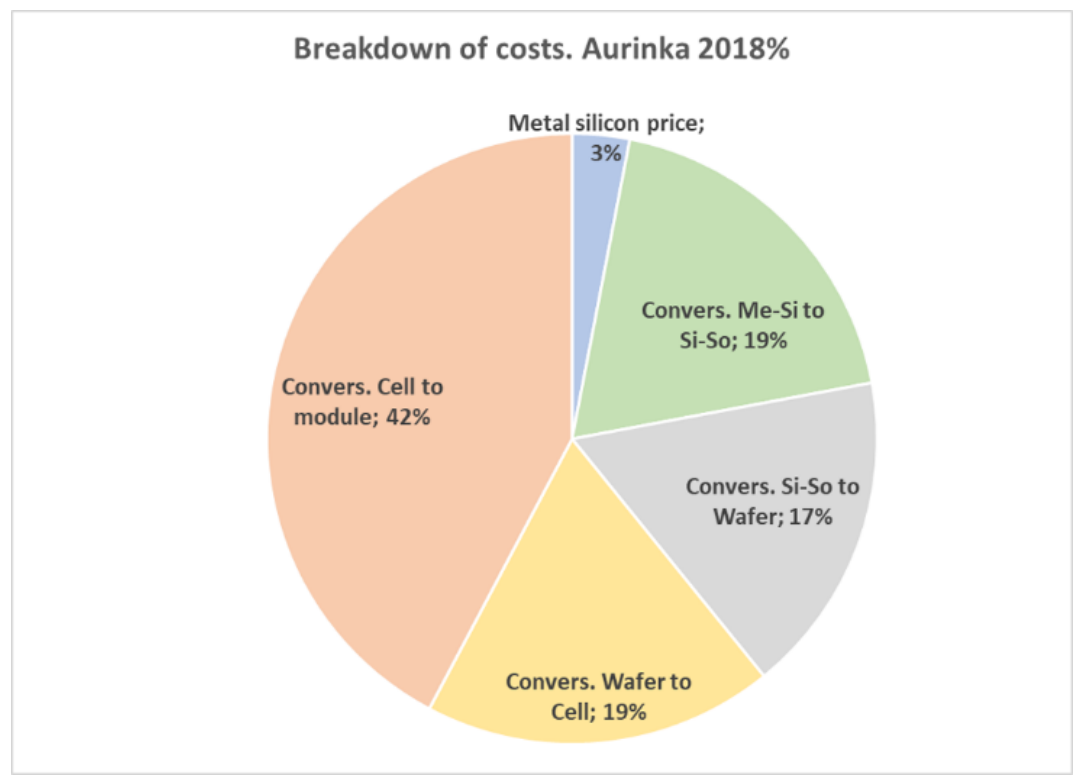

Figure 2. Module cost breakdown. Includes all the costs (cash costs, SG\&A expenses and depreciation) except for the Me-SiG where only the material price is included. Me-Si stands for metallurgical grade silicon and Si-So for solar grade silicon.

Aurinka PV Group, the engineering team that has been developing the industrialization of the project, has created a simulation software specific for the purification process, that, together with the inputs of every single data from all the steps of the overall process, is able to provide the cash costs for different scenarios. In that way, the consumption of electricity, manpower, consumables, spare parts, etc., are considered. As it is a "real time" software, the lag of every single machine shows up as a natural consequence of the eventual lack of simulated resources (operators, forklifts, furnaces, etc.). 
Then the uptime is well calculated, and the optimal number of resources assessed to minimize the cash cost and maximize the productivity. By means of that software and the optimization of the process, the cash cost of a large-scale factory has been calculated to be below $7 \$ / \mathrm{kg}$, being price of electricity and manpower cost considered for Spanish location.

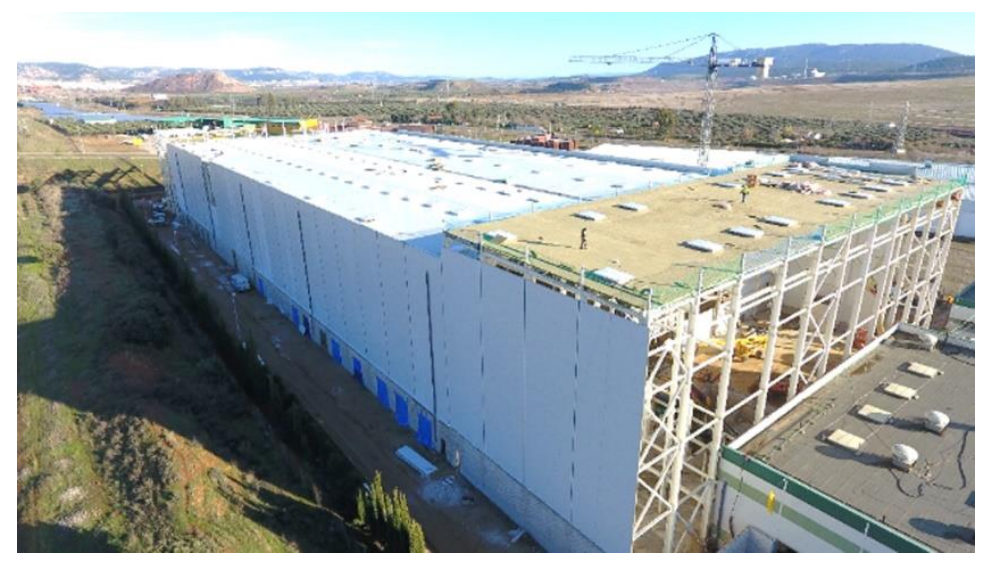

Figure 3. UMG-Si production factory at Puertollano (Spain).

It is already well established that the UMG-Si produced by the mentioned process can be utilized $100 \%$ in the charge to multicrystalline ingots growth, without the need of mixing with polysilicon. Several tests have also been done in single crystal (monocrystalline) growing using 100\% UMG-Si with good results. However, such tests have not been brought to mass production yet. UMG-Si, because of its low cost and physical characteristics, has the potential to keep multicrystalline in the competitive race with the other PV technologies including the most recently fast-growing single crystal and keep a notable share of the market.

To illustrate this competition between the two major crystalline silicon technologies, it will be explained, in the following discussion, recent technology developments and implementations which are contributing to their respective success:

- Diamond-Wire Saw (DWS), introduced to the market gradually during the past 5 years, is considered a disruptive wafer sawing technology due to its lower costs of ownership and the higher throughput (around 60 wafers per kg of certified silicon) compared to traditional Slurry Cut Wire Saw (SWS). Nevertheless, while those advantages have been applied effectively to monocrystalline ingots, the throughput for multicrystalline has been slightly less (around 55 wafers per kg) than in mono. Moreover, the multicrystalline technology has suffered from problems of texturization due to the soft wafer surface resulting from the DWS.

- PERC: The implementation of high efficiency cell architectures as Passivated Emitter and Rear Cell has also adversely affected the multicrystalline technology variant. Due to the optimization of surface passivation of the cells, the bulk lifetime, lower in multi than in mono, has become the limiting factor of cell efficiency.

- LeTID or CID: The Light at elevated Temperature Induced Degradation (LeTID) or the Current Induced Degradation (CID) has become a deleterious effect on multicrystalline PERC solar cells. It results in a deep degradation of performance of the module once installed in real outdoor conditions [2]. Boron oxide complexes (B-O) or iron boron pairs (FeB) cannot be considered responsible for LeTID or CID, as they are for Light Induced Degradation (LID). It is currently assumed that hydrogen introduced for passivation plays an important role in this degradation [3].

Nevertheless, several technology steps have recently proven to be effective countermeasures that minimize or even eliminate these adversely effects. Among those are extended phosphorus diffusion gettering (ePDG), black silicon (B-Si), mono-like crystallization and current induced recovery (CIR): 
- ePDG: Phosphorus diffusion gettering happens naturally during the emitter diffusion step of the conventional p-type cell process flow, improving the bulk minority carrier lifetime significantly. Since the 1970s, phosphorus doping is done at industrial level using $\mathrm{POCl}_{3}$ thermal diffusion [4]. The main advantages of this technology are the low operational costs and the commercial readily availability of high-throughput equipment. Normally, phosphorus diffusion is carried out in two steps, first a phosphosilicate glass (PSG) layer is deposited on the surface of the wafer and afterwards the phosphorus is forced to move deeper in a drive-in step, which is carried out at a lower temperature and without the feeding of the phosphorus source. The impurity gettering happens in the phosphorus diffusion and other thermal steps of cell processing, such as passivation [5], low thermal annealing (LTA) or contacts co-firing [6]. This phenomenon is responsible for the better bulk lifetime and emitter recombination properties of the processed material when compared to the as-grown material. Nevertheless, it is a complex phenomenon in which several competing mechanisms take place [7], including internal impurities gettering (migration to grain boundaries, dislocation or precipitates), external impurities gettering (migration to the surface), defects reconfiguration or bulk passivation of defects or changes in the surface recombination velocity (by hydrogen for example, during SiNx layer formation). In the case of UMG-Si, and other solar grade materials obtained by metallurgical purification, the presence of impurities, especially iron, is higher than in a p-type multicrystalline silicon made from polysilicon. This element is mainly present in the form of interstitial iron and can be significantly reduced by the application of tailored process parameters $[8,9]$, without increasing neither the overall cost nor the complexity of the operations. In our case an "extended" PDG (or ePDG) should be used, encompassing engineering intervention in all the thermal processes during solar cells production in addition to phosphorus diffusion.

- B-Si: Black silicon is being introduced in a massive scale into production lines [10]. Due to the reduction of reflection, B-Si has been able to increase the absolute efficiency of multicrystalline solar cells up to $0.4 \%$ abs [11]. Moreover, according to Pasanen et al. [12], both PDG and B-Si techniques in combination, have additive and synergetic effects that potentiate each other, opening the possibility of using metallurgically refined silicon to high efficiency solar cells. The combination of B-Si and PDG together with the usage of high-quality silicon purified by metallurgical route, also known as upgraded metallurgical grade silicon (UMG-Si), can contribute to lower production cost of PV ( $\$ / \mathrm{kWp}$ ). Pasanen et al. have also published the positive impact of B-Si on solar cells in terms of Current Induced Degradation, which emphasizes even more the possibilities of UMG-Si [3]. Under an economical assessment, Modanese et al. [13] calculated a relative cost reduction of up to $11.7 \%$ for a multicrystalline B-Si + PERC solar cell compared with a monocrystalline PERC solar cell, being most of the reduction related to feedstock and ingot growing.

- LeTID recovery or current induced recovery (CIR): There are several techniques that can mitigate or even eliminate the LeTID or CID of the cells. Most of these consist in applying temperature, current or light [14-16]. In fact, CIR has been already tested industrially and implemented successfully in productions lines. This method accelerates the LeTID, that typically takes thousands of hours, and provokes the final recovery of the solar cells that would otherwise takes place naturally in the field only after several months.

- Mono-like: This silicon growth technology was already introduced in the industry in 2012 [17] with good results in terms of quality, but suffered of structure inhomogeneity along the ingot height. This, together with the cost of the seeds and the rapid and successful introduction of the high performance multicrystalline (HPM) growth technique, kept the mono-like (also called mono-cast) out of the business. Nevertheless, companies among the PV leaders are currently revisiting and adopting this technology [18], indicating that the previous drawbacks can be overcome.

For all these reasons mentioned above, it is believed that the multicrystalline wafers can stand the boost of mono and keep a high market share in the future. That was one of the conclusions of the last EU PVSEC [19]. High quality UMG-Si can contribute to this, not only because of the lower production 
costs, but also because of lower energy budget (around $30 \mathrm{kWh} / \mathrm{kg}$ ), lower specific Capex (15-30 \$/kg, depending on the capacity) and lower carbon footprint.

In the next sections of this paper the process steps followed to accomplish the test will be explained in detail, starting from the MeG-Si production and finishing with the module production and characterization. This is the occasion to give a detailed description of the UMG-Si process as it is under construction at the Puertollano plant. The whole test, from silicon purification to module production, was inspected by TÜV Rheinland [20] (for more details see Results and Discussion below).

\section{Materials and Methods}

\subsection{Carbo-Reduction to Obtain MeG-Si}

The fabrication process for metallurgical silicon is the carbo-reduction of quartz by coal in a submerged electrode arc furnace according to the reaction:

$$
\mathrm{SiO}_{2}+2 \mathrm{C}=\mathrm{Si}+2 \mathrm{CO}
$$

The silicon production furnace is a crucible of about $10 \mathrm{~m}$ in diameter and $3 \mathrm{~m}$ deep lined with refractory material, powered by a three-phase electrode system. The furnace has many auxiliary facilities around as depicted in Figure 4.

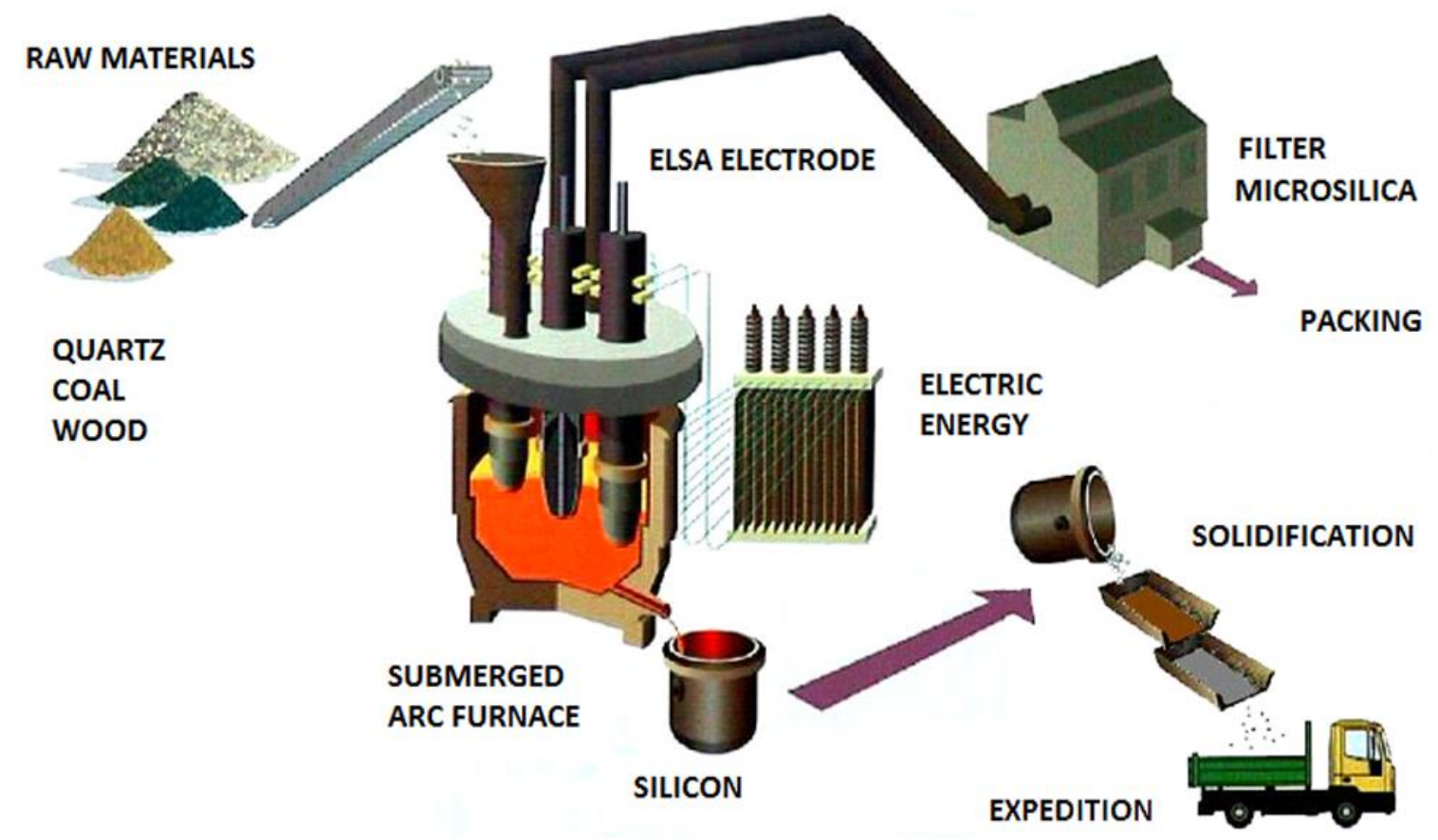

Figure 4. Me-Si production furnace and auxiliary facilities.

In a continuous process, the furnace is loaded with raw materials and the resulting liquid metal is tapped continuously. Silicon's melting point is $1415^{\circ} \mathrm{C}$. The charge is heated up to a temperature around $2000{ }^{\circ} \mathrm{C}$ by means of three electrodes submerged in the raw material mixture (Figure 5), providing three-phase current. At these temperatures the reduction of silica occurs, resulting in metal silicon. The molten silicon poured out from the reaction vessel is subsequently refined by slag treatment or gas purge. During the refining, oxide and carbide particles are removed, adjusting the metal composition.

After refining, the melt is poured for solidification, cooled down, crushed and milled. The electrical power consumption is about 11-13 MWh per ton of silicon produced in state-of-the-art processes. Excess energy provided by the furnace and not consumed in reaction (1) (3-5 MWh/t of 
silicon) can be reclaimed in a heat recovery station or used to produce electricity in a cogeneration plant. The overall reaction as expressed in Equation (1) is, in fact, the summary of several steps [21]. When heating, volatiles from carbon are removed upwards and the quartz goes down with carbon into the oven. In the inner zone (zone 2, Figure 6).

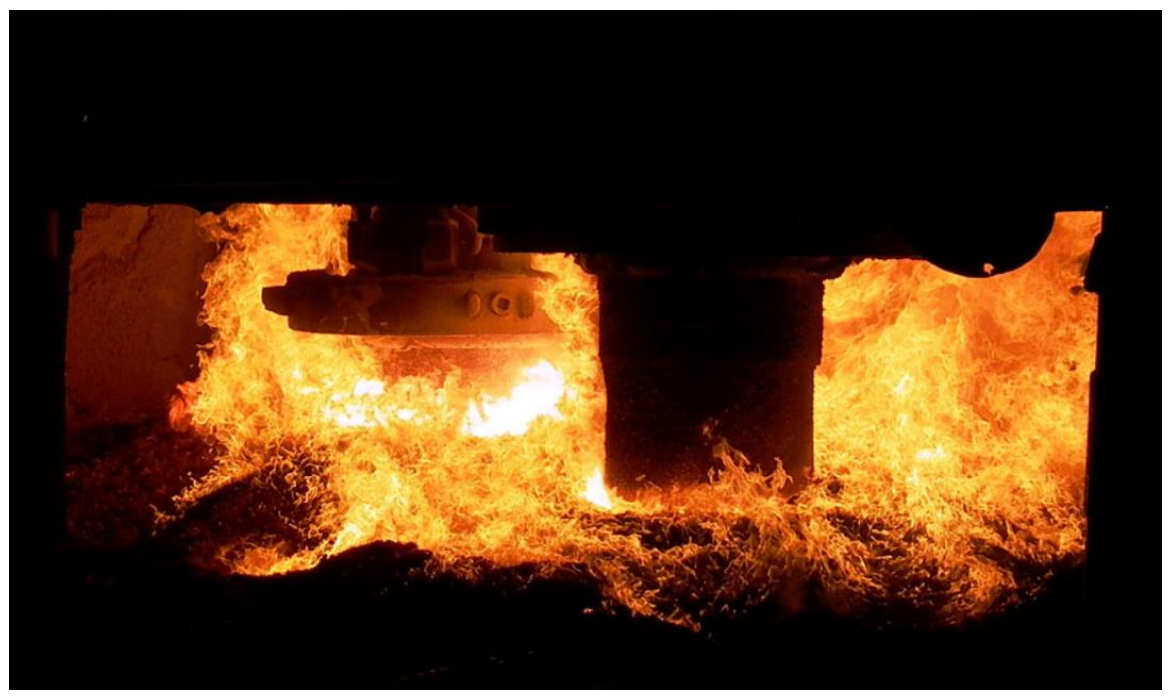

Figure 5. Picture of the upper part (zone 5, Figure 6) of a submerged ARC electrode furnace during process showing two electrodes in the center of the picture.

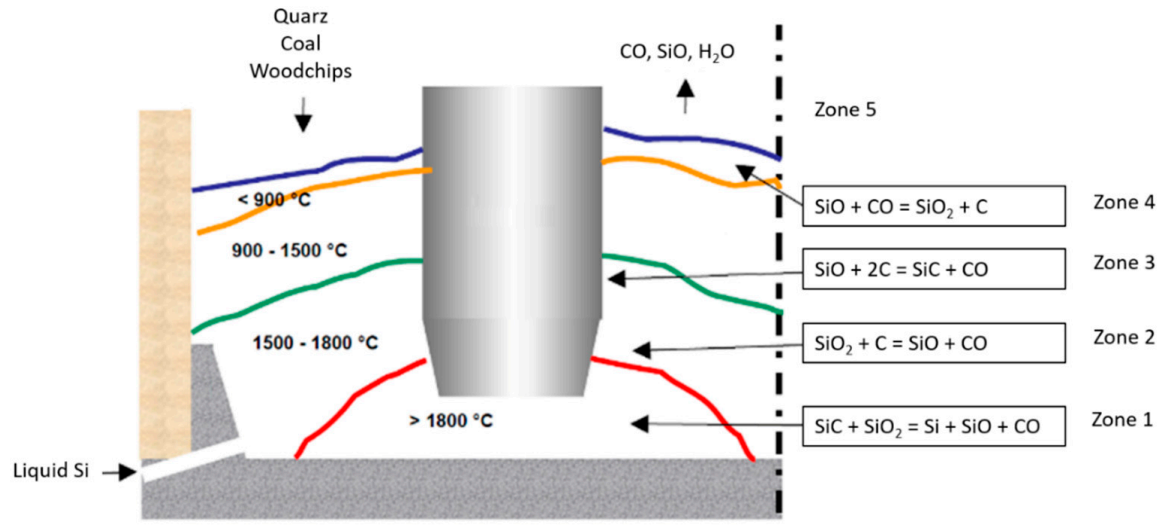

Figure 6. Sketch of the electrode and different zones inside a submerged ARC electrode furnace.

$\mathrm{SiO}$ is generated according to:

$$
\mathrm{SiO}_{2}+\mathrm{C}=\mathrm{SiO}+\mathrm{CO}
$$

The generated gaseous and unstable (metastable) $\mathrm{SiO}$ rises to an intermediate height (zone 3 ) and reacts with more $\mathrm{C}$ to give $\mathrm{SiC}$ according to:

$$
\mathrm{SiO}+2 \mathrm{C}=\mathrm{SiC}+\mathrm{CO}
$$

The SiC descends to the hot zone of the oven (zone 1; Figure 6) and with remaining quartz generates Si:

$$
\mathrm{SiC}+\mathrm{SiO}_{2}=\mathrm{Si}+\mathrm{SiO}+\mathrm{CO}
$$

For the good performance of the oven, it is critical to capture the generated $\mathrm{CO}$, otherwise the yield of the furnace decreases significantly. To recover this CO there is only one mechanism, in the upper part of the oven (zone 4): 


$$
\mathrm{SiO}+\mathrm{CO}=\mathrm{SiO}_{2}+\mathrm{C}
$$

The product is traditionally called silicon metal or metallurgical grade silicon MeG-Si. The chemical characteristics of the MeG-Si traded in the market, fall within the following ranges:

- Metals (principally $\mathrm{Fe}, \mathrm{Al}, \mathrm{Ca}$ followed by Ti, $\mathrm{Mn}$ and traces of transition metal): 1 to $4 \%$

- Boron: 8-50 ppmw

- Phosphorus: 10-50 ppmw

Aluminum and calcium content can be significantly reduced by oxidation in the refining ladle (slag or gas treatment-see above) while the level of iron and the other transition metals depend ultimately on the purity of the quartz and the type of coal used. It is possible to mix several types of quartz and reductants in the feeding charge to tailor the final composition of the metallurgical grade silicon (with less than $0.2 \%$ ppmw of impurities) more suitable as starting point of the purification process.

\subsection{Silicon Purification}

For photovoltaic purposes, the MeG-Si must be purified either by direct (metallurgical treatment) or indirect (chemical treatment) route [22]. Regarding the FerroSolar UMG process, MeG-Si has been used as a starting material. As mentioned in the previous section, the characteristics of MeG-Si are established standards in the market. An oversimplified description of the process selected by FerroSolar is depicted in Figure 7.

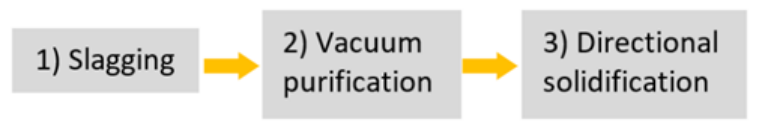

Figure 7. Descriptive sketch of the purification process at FerroSolar.

\subsubsection{Slagging}

Silicon produced through carbothermic reduction of quartz contains about $99 \%$ of $\mathrm{Si}$, with $\mathrm{Fe}, \mathrm{Al}$, $\mathrm{Ca}, \mathrm{Ti}, \mathrm{C}$ and $\mathrm{O}$ being the most common impurities. The less noble elements, e.g. $\mathrm{Al}$ and $\mathrm{Ca}$, can be significantly removed by oxidation (see refining of MeG-Si above). Fe and the transition elements are not affected by oxidation. These can be efficiently removed by directional solidification (DS), which also impacts, although to a lesser degree, to other elements. Boron and phosphorus are present in tens of ppmw in MeG-Si. Since these elements are respectively $\mathrm{p}$ and $\mathrm{n}$ silicon dopants, they must be closely controlled in solar grade silicon. Unfortunately, both impurities are difficult to remove by traditional purification routes such as directional solidification or acid leaching, due to their large segregation coefficients $K_{B}=0.8$ and $K_{P}=0.35$ [23]. Therefore, several alternative methods have been studied and developed to remove boron such as slag refining [24,25] plasma refining [26], and gas refining [27,28].

Slag refining is well established in many metallurgical processes and can be operated on a large industrial scale. This represents a great advantage over other boron removal methods that are not easily scalable. Most of the known slag-forming composition include binary, such as $\mathrm{CaO}-\mathrm{SiO}_{2}$, ternary $\mathrm{CaO}-\mathrm{Al}_{2} \mathrm{O}_{3}-\mathrm{CaO}, \mathrm{CaO}-\mathrm{MgO}-\mathrm{SiO}_{2}, \mathrm{CaO}-\mathrm{Na}_{2} \mathrm{O}-\mathrm{SiO}_{2}, \mathrm{Al}_{2} \mathrm{O}_{3}-\mathrm{BaO}-\mathrm{SiO}_{2}$, and even quaternary compositions as $\mathrm{Al}_{2} \mathrm{O}_{3}-\mathrm{CaO}-\mathrm{MgO}-\mathrm{SiO}_{2}$ [29].

In slag refining, metallurgical grade silicon is melted in contact with a slag-forming compound. In case of boron the basic principle of slag purification is the oxidation of boron at the Si/Slag interface, followed by the dissolution of the oxidized boron in the slag phase. $\mathrm{B}$ as impurity to silicon can be oxidized to $\mathrm{BO}, \mathrm{B}_{2} \mathrm{O}, \mathrm{B}_{2} \mathrm{O}_{3}, \mathrm{BO}_{2}$, and $\mathrm{B}_{2} \mathrm{O}_{2}(\mathrm{~g})$. Thermodynamics of boron removal with slags have been studied in great detail. Most of these studies focused on the calculation and optimization of the equilibrium conditions between $\mathrm{Si}$ and slag. In general, the efficiency of boron removal from silicon is increased with increasing temperature and with slag basicity. Depending on slag composition, boron removed from silicon can remain concentrated in the slag or volatilized to the atmosphere as 
gaseous compounds. The general principle for plasma refining and gas refining is essentially the same, oxidation of boron to gaseous compounds at high temperature, and volatilization of said compounds to the atmosphere. The first step of this UMG process includes a reactive slagging treatment, capable of decreasing boron content in silicon to below 0.2 ppmw.

\subsubsection{Vacuum Refining}

As mentioned above, a major challenge in silicon purification through metallurgical routes is the removal of phosphorus. Vacuum refining can be considered as an alternative purification route in which the volatile impurities, such as phosphorus, are effectively removed.

From a thermodynamics point of view, the principle of an effective removal of impurities from a liquid metal under vacuum at elevated temperature is the difference of the respective vapor pressure between the metal to be refined and the impurities. According to this approximation, dissolved impurities with higher vapor pressure than silicon are expected to evaporate away.

Thermodynamics alone is not enough, since the evaporation of an impurity may be too slow to proceed practically. Therefore, the evaporation of phosphorus must be studied also from a kinetic point of view. Depending on experimental conditions, phosphorus evaporates as $\mathrm{P}_{4}(\mathrm{~g}), \mathrm{P}_{2}(\mathrm{~g})$ and $\mathrm{P}(\mathrm{g})$. In metallurgical grade silicon, evaporation as $\mathrm{P}(\mathrm{g})$ becomes dominating at concentrations of phosphorus below 50 ppmw and high temperatures [30,31]. Under these conditions, evaporation follows a first order reaction:

$$
[P]=[P]_{i} \exp \left(-K_{p} \frac{A}{V} t\right)
$$

where $[P]$ and $[P]_{i}$ are, respectively, the final and initial phosphorus concentration in silicon, $A$ is the surface area of the melt $\left(\mathrm{m}^{2}\right), V$ is the volume of the melt $\left(\mathrm{m}^{3}\right), K_{p}$ is the evaporation rate constant $(\mathrm{m} / \mathrm{s})$ and $t$ is the time (s). Detailed studies on reaction mechanism concluded that the removal of phosphorus from silicon occurs through five steps: (i) transport of phosphorus close to the surface of the melt; (ii) transport of phosphorus to the surface through the interface layer; (iii) evaporation at the melt surface; (iv) mass transport of gaseous phosphorus and (v): condensation of phosphorus [32,33].

Several silicon recycling treatments under vacuum at high temperatures have been conducted during the last few years at FerroSolar's pilot plant in Sabon (Spain), in a graphite resistance furnace [34]. $490 \mathrm{~kg}$ of silicon with a starting phosphorus concentration of 3 ppmw were treated in each run, in high density isostatic graphite crucibles. The goal of these experiments was to check the influence of experimental parameters on the efficiency of phosphorus removal. Internal pressure in the furnace was maintained in the range 0.1-0.3 Pa throughout the treatment. As a result of these vacuum treatments, concentration of phosphorus in purified silicon was in the range of $0.1-0.2 \mathrm{ppmw}$, and mass transfer coefficients of up to $7 \times 10^{-5} \mathrm{~m} / \mathrm{s}$.

As expected, increasing treatment temperature resulted in increased evaporation rates. Process temperature has been stabilized within the range $1600-1700^{\circ} \mathrm{C}$. Although higher temperatures lead to faster evaporation rates, they would have a detrimental effect on the lifetime of the different components of the furnace, thus a compromise between temperature and process time has been reached to optimize the production costs, in which the lifetime of the components have been also considered in the calculation. These results are in good agreement with the kinetic model in which phosphorus removal rate is controlled by the reaction at the interface and the mass transport in the gas phase.

\subsubsection{Directional Solidification}

Directional solidification is an essential step to obtain solar grade silicon. The basis of the process is the equilibrium established between the concentration of an impurity in the solid and liquid silicon. As a consequence of the general tendency of impurities to concentrate in liquid silicon, high purity solid silicon is obtained in an economical feasible way.

Segregation of each impurity is given by its own segregation coefficient, which is the ratio between the equilibrium concentrations of the element in solid and liquid silicon. The lower the coefficient, the 
better the purification. Most of the impurities in silicon have segregation coefficients $<<<1$, with the exception of boron and phosphorus [35].

From a practical point of view, the requirements for an efficient directional solidification are twofold: low solidification rate and homogeneous solidification front. UMG process includes directional solidification as refining method to remove most of the metallic impurities contained in the starting MeG-Si. It is worth noting that the process makes use of a non-conventional directional solidification, different from commercial multicrystalline ingot techniques and therefore with lower costs and higher throughput. At the end of the purification process, the material characteristics are the following:

- P-type silicon bricks and chunks

B $<0.2 \mathrm{ppmw}$

$P \quad=0.1-0.3 \mathrm{ppmw}$ (the concentration of $P$ is tuned to compensate the boron)

- $\Sigma[\mathrm{Me}]<0.5$ ppmw (Me being Fe, $\mathrm{Al}$, transition, alkaline and alkaline earth elements).

\subsection{Ingot Growing and Wafering}

P-type high performance multi-crystalline ingots (HPMC) were grown in industrial-scale DS furnaces (GT450, adapted to grow HPMC ingots) in this trial [36]. An advantage of the UMG-Si feedstock is that it is mainly in the form of bricks (compared to the chunks coming from the chemical route). This allows a much higher crucible filling that can be translated into $20 \%$ cost reduction for ingot growing.

The heaters provide heat to the hot-zone, in which the heat is preserved by the insulation. The heat exchange block was installed below the crucible to take heat away from the hot-zone. The flowing inert argon gas was applied to purify the growth environment in the furnace. $650 \mathrm{~kg}$ UMG-Si material were loaded into the crucible on a layer of silicon seeds. Additionally, small quantities of dopants were added to ensure resistivity ranging from 1.0 to $3.0 \Omega \cdot \mathrm{cm}$. The crucible with inner dimensions of $(890 \times 890 \times 540) \mathrm{mm}$ was covered with silicon nitride coating to prevent sticking and impurity dissolution. The used silicon seeds were polysilicon chips with average size $1 \mathrm{~mm}$, the height of the seed layer was about $20 \mathrm{~mm}$ (Figure 8a).

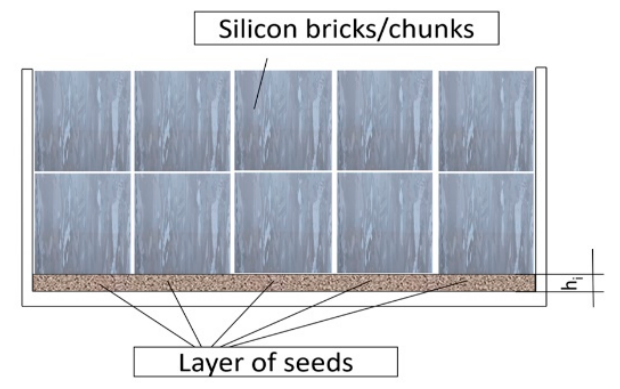

(a)

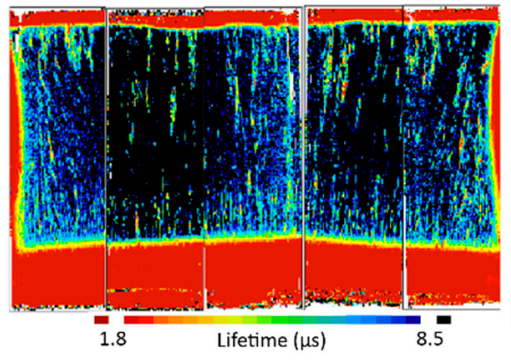

(b)

Figure 8. (a) Sketch of the charge of the directional solidification furnace. Crucible dimensions: $890 \times 890 \times 540 \mathrm{~mm}$, layer of seeds $\mathrm{h}_{\mathrm{i}}=50 \mathrm{~mm}$; (b) Lifetime mapping of a representative ingot.

During the melting process, the temperature gradient and melting process were well controlled to preserve the silicon seed crystals with an un-melted height of about $10 \mathrm{~mm}$.

The growing HPM technique was applied for obtaining specific structure with small grains and with random orientation along the ingot height. After the completion of solidification and cooling, each silicon ingot was cut into 25 bricks with a square area of $(156.75 \times 156.75) \mathrm{mm}$.

The bricks were polished and controlled by standard procedures. Inclusions and un-melted seeds were identified using the Intego Orion IR block inspection system. Lifetime measurements were done with the Semilab WT-2000D. The ingot lifetime was above $5 \mu$ s (Figure 8b). 
Growing yield were on the same level compared with usual polysilicon ingots. Later the bricks were cut into wafers by two different methods: (a) slurry-based sawing obtaining wafers with average thickness of $195 \mu \mathrm{m}$, and (b) diamond wire sawing (DWS) obtaining wafers with average thickness of $180 \mu \mathrm{m}$. State-of-the-art $70 \mu \mathrm{m}$ diamond wire was used to guarantee the surface quality. Yield of sawing was on the same level compared with usual polysilicon bricks for both sawing methods.

\subsection{Solar Cells Production}

\subsubsection{Al-BSF Cells}

Approximately 100,000 wafers were sent to a Tier-1 solar cells producer, also responsible for module manufacturing. The wafers, after passing the initial incoming material inspection, were introduced into the production line.

Aluminum Back Surface Field (Al-BSF) solar cells were produced in a conventional production line, where no adjustment was made for adjusting the production parameters of the machines to the peculiarities of the incoming UMG-Si wafers. So, it is reasonable to expect a certain improvement of efficiency and yield in case the recommendable fine-tuning of the line to a new provider would be performed. The process is depicted in Figure 9, and consists of the following steps:

1. The first stage consists in a nitric and hydrofluoric acid etching for surface cleaning, saw damage removal and texturing.

2. The wafers are placed back to back to be introduced into quartz furnaces to perform a Low Pressure Chemical Vapor Deposition (LPCVD) of a thin film of phosphosilicate glass (PSG) composed of $\left(\mathrm{P}_{2} \mathrm{O}_{5}\right)_{x}\left(\mathrm{SiO}_{2}\right)_{1-\mathrm{x}}$.

3. In the next step the diffused phosphorus from the back side is removed. For that, a back side chemical etching is performed, followed by a rinse in another chemical etching to achieve the edge isolation and avoid the edge shunts.

4. Annealing is a pre-treatment process prior to antireflective coating (ARC) of silicon nitride. In this short process a thin film of silicon dioxide is deposited to increase the Potential Induced Degradation resistance of the solar cell, what is commercially called PID free solar cells [37].

5. Antireflective Coating (ARC). Silicon nitride $\left(\mathrm{SiN}_{\mathrm{x}}: \mathrm{H}\right)$ coating of approximately $75 \mathrm{~nm}$ thick is deposited on the front surface by means of a Plasma Enhanced Chemical Vapor Deposition reactor (PECVD) to increase light absorption. This coating is also suited for surface passivation due to the field effect passivation [38]. The Hydrogen present in the silicon nitride coating is also involved in a chemical passivation [39].

6. Front and rear contacts as well as the Aluminum coating responsible for the Back Surface Field (BSF) formation are printed in a double printing process, saving Ag consumption and reducing the shadow losses [40].

7. Co-firing furnace is used to make the drive through of the contacts [41].

8. In the last step of the solar cells production, the solar cells undergo an electroluminescence test (EL test) [42] where a defect detection software is used.

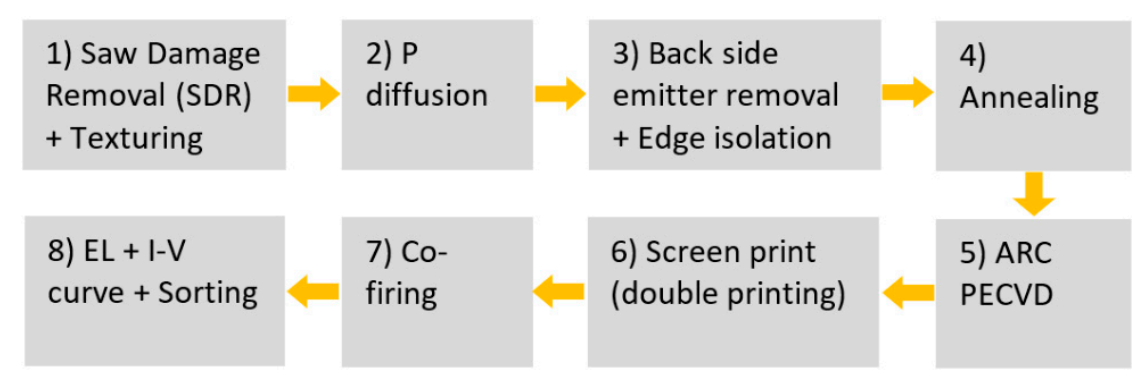

Figure 9. Descriptive sketch of Al-BSF solar cells production. 


\subsubsection{Black Silicon + PERC Cells}

45,000 wafers (DWS) were sent to another and independent solar cell producer. The technology used in this case was black silicon + PERC as depicted in Figure 10.

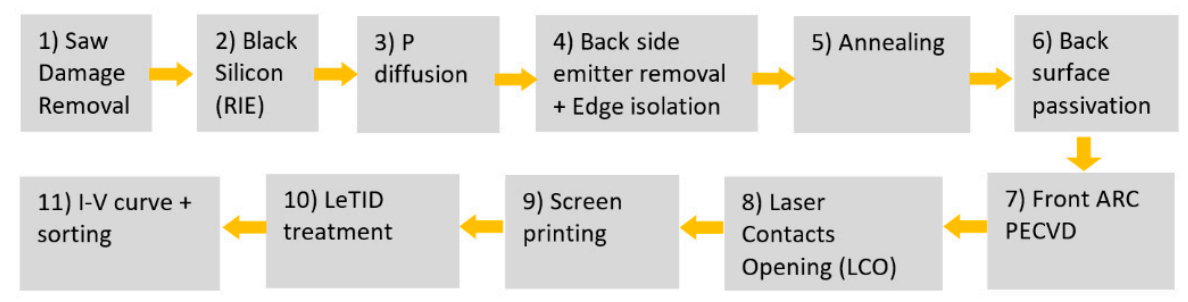

Figure 10. Descriptive sketch of B-Si + PERC solar cells production.

Besides the common production steps of Al-BSF process, mentioned above, the following additional processes are introduced to obtain black silicon + PERC solar cells:

2) Black silicon (B-Si) nano-texture. The technology used to provoke a nano-texture on top of the wafer is reactive ion etching (RIE). $\mathrm{SF}_{6}$ and $\mathrm{O}_{2}$ gases are introduced into the reaction chamber. In there, a synergetic mechanism of chemical etching, passivation and ion bombardment takes place, thus, nano-structures are formed reducing considerably the reflectance of the wafer $[10,43]$.

6) Back surface passivation. To reduce the back surface recombination a passivation layer is deposited in the back surface which gives name to the passivated emitter and rear cells (PERC) [44,45]. In this test, an $\mathrm{Al}_{2} \mathrm{O}_{3}$ film is deposited onto the back surface, acting as a passivating agent. After the oxide deposition, a capping layer of silicon nitride was deposited. The role of this capping layer is to behave as a back reflector for long wavelength radiation as well as being a barrier for $\mathrm{Al}$ metal contacts. Also, this silicon nitride reduces the surface recombination velocity due to its negative charge [46]. Both films were deposited by means of PECVD.

8) Laser Contacts Opening. Backside openings through the passivation stack were made by a nanosecond pulsed laser.

9) To minimize the light at elevated temperature degradation (LeTID) [14-16] a post-treatment of the cells is performed.

\subsection{PV Modules Production}

The modules manufacturing has followed a standard production process (Figure 11). The same bill of materials (BOM) and production line were used for both, UMG-Si and polysilicon solar cells.

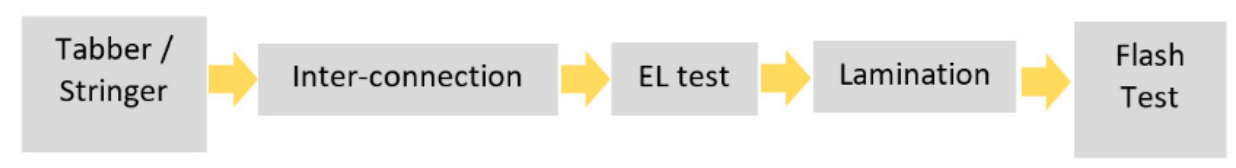

Figure 11. Descriptive sketch PV module production.

\section{Results and Discussion}

After several tests at a small production scale with good results [47], a mass production test was performed with the solar silicon generated in its direct purification process. For that, several tons of silicon were used to grow multicrystalline HPM silicon. Then the wafers were sent to two different Tier-1 solar cell and module producer, where both Al-BSF and B-Si + PERC modules were produced. The results of the cells and modules had to be compared with those obtained with polysilicon base material. For sake of external and independent audition, all the production steps throughout the whole value chain, from silicon purification to module production, were inspected by the TÜV Rheinland. One inspector from TÜV has been accompanying the technicians in all the production lines to check 
the production of the material and that the incoming raw material of one production line were the same that outwent from the previous production line. Thus, the whole process and material tracking was certified by an external auditor [21].

Since different companies have different cell to module losses (CTM losses) depending on the bill of materials (BOM), module design and manufacturing procedure [48,49], only the solar cells results will, in the following, be compared with those obtained with polysilicon. In any case, as an example, the average module performances are reported in Table 1 (only data for 72 cells modules are shown).

Table 1. Average values of module production.

\begin{tabular}{cccccccc}
\hline Cell Technology & $\begin{array}{c}\text { Pmax } \\
\text { [W] }\end{array}$ & $\begin{array}{c}\text { Voc } \\
\text { [V] }\end{array}$ & $\begin{array}{c}\text { Isc } \\
{[\mathbf{A}]}\end{array}$ & $\begin{array}{c}\text { Vmpp } \\
{[\mathbf{V}]}\end{array}$ & $\begin{array}{c}\text { Impp } \\
{[\mathbf{A}]}\end{array}$ & $\begin{array}{c}\text { FF } \\
\%\end{array}$ & Counts \\
\hline Black silicon+ PERC & 354.4 & 47.48 & 9.70 & 38.21 & 9.28 & 77.00 & 300 \\
Al-BSF & 325.1 & 45.73 & 9.32 & 37.13 & 8.76 & 76.31 & 1350 \\
\hline
\end{tabular}

As it is shown in Table 2, the highest efficiency was obtained with B-Si + PERC (as expected). The average efficiency is $(20.4 \pm 0.6) \%$ and the record efficiency $20.76 \%$ (not shown in the table). As previously emphasized, no tune of parameters of production lines was done to perform these tests.

Table 2. Average values of solar cells production. Comparison between polysilicon and UMG-Si. The dashes in the cells stand for data not given by the producer. Column Red.\% ${ }_{\text {rel }}$ refers to relative reduction in efficiency between UMG and poly.

\begin{tabular}{|c|c|c|c|c|c|c|c|c|c|c|c|c|}
\hline \multicolumn{2}{|c|}{ Solar Cells Results } & $\begin{array}{c}\text { Pmpp } \\
\text { [W] }\end{array}$ & $\begin{array}{l}\text { Voc } \\
\text { [V] }\end{array}$ & $\begin{array}{l}\text { Isc } \\
{[A]}\end{array}$ & $\begin{array}{l}\mathrm{FF} \\
\%\end{array}$ & $\begin{array}{c}\text { Eta } \\
\%\end{array}$ & $\begin{array}{l}\text { Red. } \\
\%_{\text {rel }}\end{array}$ & $\begin{array}{l}\text { Umpp } \\
\text { [V] }\end{array}$ & $\underset{[A]}{\operatorname{Impp}}$ & $\begin{array}{l}\text { Rsh } \\
{[\Omega]}\end{array}$ & Counts & TEST \\
\hline \multirow{2}{*}{ Al-BSF } & UMG & 4.549 & 0.632 & 9.03 & 79.74 & 18.515 & \multirow{2}{*}{$0.68 \%$} & 0.535 & \multirow[t]{2}{*}{8.501} & 141 & \multirow[t]{2}{*}{2000} & TEST 1 [1] \\
\hline & Poly & 4.579 & 0.634 & 9.06 & 79.69 & 18.642 & & & & 131 & & Prod.A \\
\hline \multirow{2}{*}{ Al-BSF } & UMG & 4.522 & 0.632 & 9.02 & 79.27 & 18.404 & \multirow{2}{*}{$0.47 \%$} & 0.533 & \multirow[t]{2}{*}{8.487} & 86 & \multirow[t]{2}{*}{99,692} & TEST 2 \\
\hline & Poly & 4.543 & 0.633 & 8.98 & 79.63 & 18.490 & & & & 112 & & Prod.A \\
\hline \multirow{2}{*}{$\begin{array}{l}\text { B-Si (RIE) } \\
+ \text { PERC }\end{array}$} & UMG & 4.945 & 0.649 & 9.54 & 79.87 & 20.130 & \multirow{2}{*}{$1.37 \%$} & 0.550 & \multirow{2}{*}{8.994} & 279 & 46,197 & TEST 3 \\
\hline & Poly & 5.014 & 0.651 & 9.62 & 80.02 & 20.410 & & & & 508 & 55,396 & Prod.B \\
\hline
\end{tabular}

Considering that UMG Solar Grade Silicon is a new material on the market and characteristics are somehow different from the main stream silicon feedstock (mainly the dopants concentration), the authors consider these results to be very encouraging. Similar tests were carried out with the same silicon but using only metal catalyzed chemical etching (MCCE) nano-texturization [50], but to the best of our knowledge, the present results show a record efficiency for p-type multicrystalline UMG-Si solar cells. Moreover, the yield, in terms of breakage and rejection, is the same for both type of materials (polysilicon and UMG-Si).

Considering the comparison with polysilicon material, for which Grade I solar silicon (according SEMI PV17-0611 2011 classification) has been used (B $<0.00038$ ppmw, $\mathrm{P}<0.00110$ ppmw), the mass production test with Al-BSF gives a loss of power of $0.68 \%$ rel less than the power obtained with polysilicon wafers. In the case of B-Si + PERC the loss of power is higher, $1.37 \%$ rel. This is in concordance with the architecture of cell used. In PERC solar cells, due to the back surface passivation, the surface recombination velocity is considerably reduced, thus the bulk lifetime becomes a more influencing parameter than in the case of Al-BSF solar cells [51]. UMG-Si material, although inside specifications, is expected to contain more contaminants than polysilicon. So, the bulk lifetime, in average, is likely to be lower in UMG-Si PERC solar cells. Lower bulk lifetime is translated into lower Voc, which is the case for this silicon. However, the Voc for UMG cells is only $0.38 \%$ rel less than that for polysilicon cells. Meanwhile Isc is almost $1 \%_{\text {rel }}$ lower, which suggests a detrimental effect more related to light trapping (B-Si or ARC processes) than to bulk lifetime. Moreover, Bredemeier et al. [14], in their LeTID study of the recovery, conjectured that the "regeneration conditions need to be adapted to 
the mc-Si used". All of this makes more important the tuning of the production parameters to enhance impurity gettering, bulk defects passivation and light trapping in UMG-Si solar cells.

In Figure 12 the efficiency distribution of solar cells is shown. In case of solar cells made of UMG-Si the left tail of the distribution is more pronounced than in polysilicon. This tail contributes to reduce the average down to $20.1 \%$. However, the distribution presents the same mode both, for cells made of UMG-Si and polysilicon. Thus, working on defects engineering, passivation and production parameters, the average efficiency of UMG-Si can therefore be at par with polysilicon.

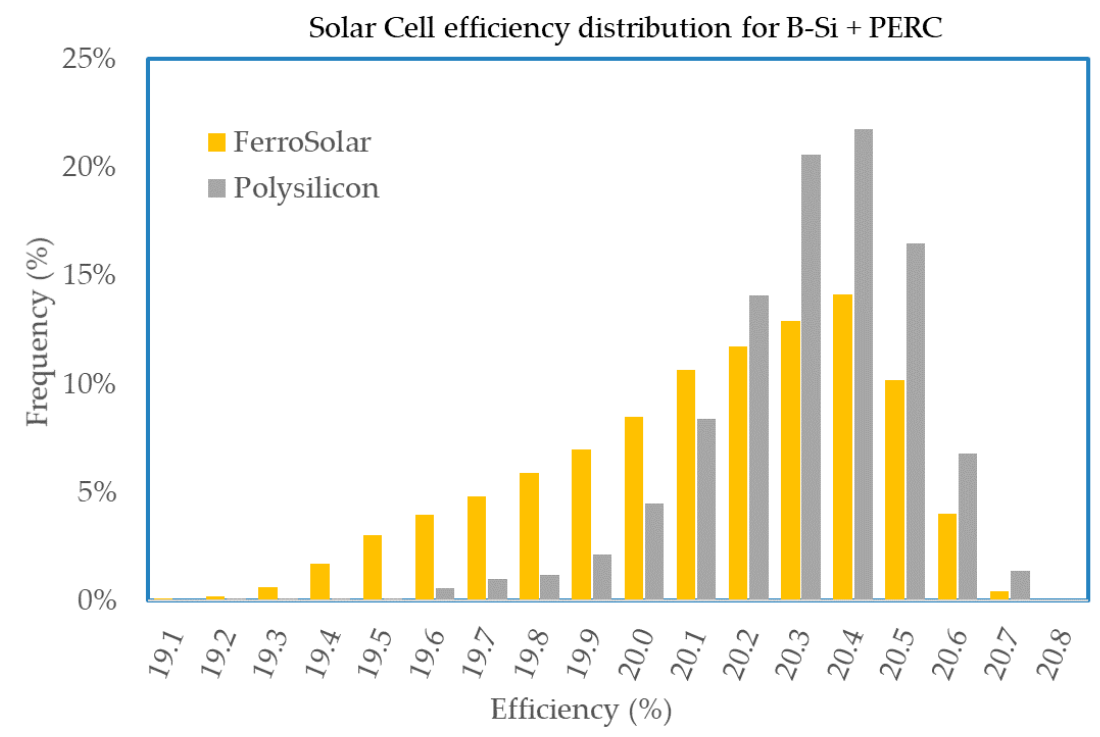

Figure 12. Distribution of efficiencies for solar cells B-Si + PERC. Comparison between polysilicon and UMG-Si.

This paper has presented a mass production test that involves the whole value chain from quartz mineral to PV in field module. The material traceability from purification to modules was carried out and certified by TÜV Rheinland. The results of the test in terms of yield and electrical parameters are close to polysilicon. To keep improving the performance, the research should continue in different directions:

At the purification level, several improvements are being developed at the laboratory scale. Management, valorization and recycling of byproducts such as silicon fines, silica, etc. are giving auspicious results. Another important step forward is the promising results in the increasing of the throughput and the reduction of energy budget.

At the cell level, ePDG, Black Silicon and passivation are being studied. Aurinka and FerroSolar are involved in a project with other research institutions to apply these techniques to our silicon and other potential UMG-Si. Parameters such as surface roughness, PSG conformality, phosphorus diffusion temperature, drive-in time, co-firing temperature, etc., must be very well matched in order to achieve the best performance.

Module degradation (after more than 3 years of outdoors operation [52]) and temperature coefficients [53] have been already studied. The modules made of UMG-Si showed no additional degradation compared with polysilicon modules, meanwhile the power thermal coefficient of modules made of UMG-Si resulted to be lower than that of polysilicon modules. Further studies are being carried out with modules resulting from this manufacturing test. So far only data for Al-BSF modules is available: after one 46 days of outdoors installation, modules made of UMG-Si showed similar degradation than those made of polysilicon. FerroSolar will continue to monitor all multicrystalline modules produced in the test and further work will be carried out on single-crystal growing with $100 \%$ UMG silicon usage. 
Author Contributions: Conceptualization, E.F.; methodology, E.F., B.C., L.M., A.S., A.P.V.; validation, E.F., B.C.; formal analysis, E.F.; investigation, E.F., T.V., J.D.; resources, E.F, L.M., A.S., A.P.V.; data curation, E.F., J.D.; writing—original draft preparation, E.F., L.M., T.V., A.S., A.P.V.; writing-review and editing, E.F., B.C., L.M.; visualization, E.F.; supervision, E.F., B.C.; project administration, E.F.; funding acquisition, E.F.

Funding: This research received no external funding.

Conflicts of Interest: The authors declare no conflict of interest.

\section{References}

1. Kost, C.; Shammugam, S.; Jülch, V.; Nguyen, H.-T.; Schlegl, T.; Mayer, J.N.; Thomsen, J.; Hartmann, N.; Senkpiel, C.; Philipps, S.; et al. Levelized Cost of Electricity: Renewable Energy Technologies; Fraunhofer ISE: Freiburg, Germany, 2018.

2. Kersten, F.; Engelhart, P.; Ploigt, H.-C.; Stekolnikov, A.; Lindner, T.; Stenzel, F.; Bartzsch, M.; Szpeth, A.; Petter, K.; Heitmann, J.; et al. Degradation of multicrystalline silicon solar cells and modules after illumination at elevated temperature. Sol. Energy Mater. Sol. Cells 2015, 142, 83-86. [CrossRef]

3. Pasanen, T.P.; Modanese, C.; Vähänissi, V.; Laine, H.S.; Wolny, F.; Oehlke, A.; Kusterer, C.; Heikkinen, I.T.S.; Wagner, M.; Savin, H. Impact of black silicon on light- and elevated temperature-induced degradation in industrial passivated emitter and rear cells. Prog. Photovolt. Res. Appl. 2018. [CrossRef]

4. Li, H.; Kim, K.; Hallam, B.; Hoex, B.; Wenham, S.; Abbott, M. POCl3 diffusion for industrial Si solar cell emitter formation. Front. Energy 2017, 11, 42-51. [CrossRef]

5. Hallam, B.; Chen, D.; Kim, M.; Stefani, B.; Hoex, B.; Abbott, M.; Wenham, S. The role of hydrogenation and gettering in enhancing the efficiency of next-generation Si solar cells: An industrial perspective. Phys. Status Solidi Appl. Mater. Sci. 2017, 214, 1700305. [CrossRef]

6. Peral, A.; Dastgheib-Shirazi, A.; Fano, V.; Jimeno, J.C.; Hahn, G.; del Canizo, C. Impact of Extended Contact Cofiring on Multicrystalline Silicon Solar Cell Parameters. IEEE J. Photovolt. 2017, 7, 91-96. [CrossRef]

7. Al-Amin, M.; Murphy, J.D. Passivation effects on low-temperature gettering in multicrystalline silicon. IEEE J. Photovolt. 2017, 7, 68-77. [CrossRef]

8. Jiménez, A.; del Cañizo, C.; Cid, C.; Peral, A. Phosphorus Diffusion Gettering Efficacy in Upgraded Metallurgical-Grade Solar Silicon. J. Electron. Mater. 2018, 47, 5068-5071. [CrossRef]

9. Kohler, D.; Raabe, B.; Braun, S.; Seren, S.; Hahn, G. Upgraded metallurgical grade silicon solar cells: A detailed material analysis. In Proceedings of the 24th European Photovoltaic Solar Energy Conference, Hamburg, Germany, 21-24 September 2009; pp. 1758-1761.

10. Rentsch, J.; Kafle, B.; Hofmann, M.; Krieg, K.; Zimmer, M. Texture etching technologies for diamond-wire-sawn mc-Si solar cells. Photovolt. Int. 2017, 38, 56-66.

11. Wang, X.; Zou, S.; Xing, G. 19.31\%-efficiency multicrystalline silicon solar cells using MCCE black silicon technology. Photovolt. Int. 2017, 35, 67-72.

12. Pasanen, T.P.; Laine, H.S.; Vähänissi, V.; Schön, J.; Savin, H. Black silicon significantly enhances phosphorus diffusion gettering. Sci. Rep. 2018, 8, 1991. [CrossRef] [PubMed]

13. Modanese, C.; Laine, H.; Pasanen, T.; Savin, H.; Pearce, J. Economic Advantages of Dry-Etched Black Silicon in Passivated Emitter Rear Cell (PERC) Photovoltaic Manufacturing. Energies 2018, 11, 2337. [CrossRef]

14. Bredemeier, D.; Walter, D.C.; Pernau, T.; Romer, O.; Schmidt, J. Production compatible remedy against LETID in high-performance multicrystalline silicon solar cells. In Proceedings of the 35th European Photovoltaic Solar Energy Conference and Exhibition, Brussels, Belgium, 24-28 September 2018; pp. 406-409.

15. Wu, J.; Yao, Z.; Zhang, D.; Xiong, G.; Jiang, F.; Sun, J.; Jaubert, J.-N.; Xing, G. Industrial Solutions to Mitigate Light-Induced Degradation in mc-PERC Cells and Modules. In Proceedings of the 35th European Photovoltaic Solar Energy Conference and Exhibition (EU PVSEC), Brussels, Belgium, 24-28 September 2018; pp. 835-838.

16. Jiang, F.; Jaubert, J.N.; Zhang, D.; Yao, Z.; Xiong, G.; Wu, J.; Xing, G. Solutions to realizing LID-controlled multi-PERC cells and modules. Photovolt. Int. 2018, 40, 57-62.

17. Guerrero, I.; Parra, V.; Carballo, T.; Black, A.; Miranda, M.; Cancillo, D.; Moralejo, B.; Jiménez, J.; Lelièvre, J.-F.; del Cañizo, C. About the origin of low wafer performance and crystal defect generation on seed-cast growth of industrial mono-like silicon ingots. Prog. Photovolt. Res. Appl. 2014, 22, 923-932. [CrossRef] 
18. GCL Produces High-Efficiency Module to Power 13 Million Homes. Available online: https://www.prnewswire.com/in/news-releases/gcl-produces-high-efficiency-module-to-power-13million-homes-694341171.html (accessed on 21 March 2019).

19. EU PVSEC: "Multicrystalline Silicon Will Not Die"-PV Magazine International. Available online: https://www.pv-magazine.com/2018/09/28/eu-pvsec-multicrystalline-silicon-will-not-die/ (accessed on 21 March 2019).

20. TÜV Rheinland Solar Energy. Factory Inspections to Confirm Raw Material Traceability of Silicon Used for Photovoltaic Module Production for FerroAtlántica; TÜV Rheiland: Cologne, Germany, 2018.

21. Schei, A.; Tuset, J.K.; Tveit, H. Production of High Silicon Alloys; Tapir: Trondheim, Norway, 1998; ISBN 9788251913171.

22. Forniés, E.; Méndez, L.; Tojeiro, M. Polysilicon vs. upgraded metallurgical silicon (UMG-Si): Technology, quality and costs. Photovolt. Int. 2016, 31, 29-38.

23. Hopkins, R.H.; Rohatgi, A. Impurity effects in silicon for high efficiency solar cells. J. Cryst. Growth 1986, 75, 67-79. [CrossRef]

24. Jakobsson, L.K.; Tangstad, M. Distribution of Boron between Silicon and CaO-MgO- $\mathrm{Al}_{2} \mathrm{O}_{3}-\mathrm{SiO}_{2}$ Slags. Metall. Mater. Trans. B 2014, 45, 1644-1655. [CrossRef]

25. Safarian, J.; Tranell, G.; Tangstad, M. Thermodynamic and Kinetic Behavior of B and Na through the Contact of B-Doped Silicon with $\mathrm{Na}_{2} \mathrm{O}-\mathrm{SiO}_{2}$ Slags. Metall. Mater. Trans. B 2013, 44, 571-583. [CrossRef]

26. Altenberend, J. Kinetics of the Plasma Refining Process of Silicon for Solar Cells: Experimental Study with Spectroscopy. Ph.D. Thesis, University of Grenoble, Grenoble, France, 2013.

27. Nordstrand, E.F.; Tangstad, M. Removal of Boron from Silicon by Moist Hydrogen Gas. Metall. Mater. Trans. B 2012, 43, 814-822. [CrossRef]

28. Sortland, Ø.S. Boron Removal from Silicon by Steam and Hydrogen. Ph.D. Thesis, NTNU, Trondheim, Norway, 2015.

29. Al-Khazraji, R.; Li, Y.; Zhang, L. Application of slag refining technique to metallurgical grade silicon purification process: A review. Funct. Mater. 2018, 25, 364-370. [CrossRef]

30. Miki, T.; Morita, K.; Sano, N. Thermodynamics of phosphorus in molten silicon. Metall. Mater. Trans. B 1996, 27, 937-941. [CrossRef]

31. Schlesinger, M.E. The Thermodynamic Properties of Phosphorus and Solid Binary Phosphides. Chem. Rev. 2002, 102, 4267-4302. [CrossRef] [PubMed]

32. Zheng, S.-S.; Abel Engh, T.; Tangstad, M.; Luo, X.-T. Separation of Phosphorus from silicon by induction vacuum refining. Sep. Purif. Technol. 2011, 82, 128-137. [CrossRef]

33. Safarian, J.; Tangstad, M. Vacuum Refining of Molten Silicon. Metall. Mater. Trans. B 2012, 43, 1427-1445. [CrossRef]

34. Souto, A.; Bullón, J.; Ordás, R.; Míguez, J.M. Industrial scale vacuum application in the Ferrosolar Project. In Proceedings of the Silicon for the Chemical and Solar Industry XII, Trondheim, Norway, 24-27 June 2014; pp. 67-76.

35. Khattak, C.P.; Ravi, K.V. Silicon Processing for Photovoltaics II; North-Holland: Amsterdan, The Netherlands, 1987; ISBN 9780080983660.

36. Buchovska, I.; Liaskovskiy, O.; Vlasenko, T.; Beringov, S.; Kiessling, F.M. Different nucleation approaches for production of high-performance multi-crystalline silicon ingots and solar cells. Sol. Energy Mater. Sol. Cells 2017, 159, 128-135. [CrossRef]

37. Luo, W.; Khoo, Y.S.; Hacke, P.; Naumann, V.; Lausch, D.; Harvey, S.P.; Singh, J.P.; Chai, J.; Wang, Y.; Aberle, A.G.; et al. Potential-induced degradation in photovoltaic modules: A critical review. Energy Environ. Sci. 2017, 10, 43-68. [CrossRef]

38. Aberle, A.G. Crystalline Silicon Solar Cells: Advanced Surface Passivation and Analysis; Centre for Photovoltaic Engineering, University of New South Wales: Sydney, Australia, 1999; ISBN 9780733406454.

39. Sopori, B.; Reedy, R.; Jones, K.; Yan, Y.; Al-Jassim, M.; Zhang, Y.; Bathey, B.; Kalejs, J. A Comprehensive Model of Hydrogen Transport into a Solar Cell during Silicon Nitride Processing for Fire-Through Metallization. In Proceedings of the 31st IEEE Photovoltaics Specialits Conference, Orlando, FL, USA, 3-7 January 2005.

40. Bottosso, C.; Martire, M.; Galiazzo, M. Fine Line Metallization through Screen and Stencil Printing. In Proceedings of the 27th European Photovoltaic Solar Energy Conference and Exhibition (EU PVSEC), Frankfurt, Germany, 24-28 September 2012; pp. 1645-1647. 
41. Ballif, C.; Huijic, D.M.; Hessler-Wyser, A.; Willeke, G. Nature of the Ag-Si interface in screen-printed contacts: A detailed transmission electron microscopy study of cross-sectional structures. In Proceedings of the Conference Record of the Twenty-Ninth IEEE Photovoltaic Specialists Conference, New Orleans, LA, USA, 19-24 May 2002; pp. 360-363.

42. Bothe, K.; Pohl, P.; Schmidt, J.; Weber, T.; Altermatt, P.; Fischer, B.; Brendel, R. Electroluminescence imaging as an in-line characterization tool for solar cell production. In Proceedings of the 21th European PV Solar Energy Conference and Exhibition (EU PVSEC), Dresden Germany, 4-8 September 2006; pp. 597-600.

43. Jansen, H.; de Boer, M.; Legtenberg, R.; Elwenspoek, M.; Elwenspoek, M.C. The black silicon method: A universal method for determining the parameter setting of a fluorine-based reactive ion etcher in deep silicon trench etching with profile control. J. Micromech. Microeng. 1995, 5, 115-120. [CrossRef]

44. Blakers, A.W.; Wang, A.; Milne, A.M.; Zhao, J.; Green, M.A. 22.8\% efficient silicon solar cell. Appl. Phys. Lett. 1989, 55, 1363-1365. [CrossRef]

45. Saint-Cast, P.; Wasmer, S.; Greulich, J.; Werner, S.; Jäger, U.; Lohmüller, E.; Höffler, H.; Preu, R. Analysis and outlook of near-industrial PERC solar cells. Photovolt. Int. 2016, 24, 52-59.

46. Urrejola, E.; Madec, A.; Pouliquen, S.; Zauner, A.; Charpentier, C.; Hong, J. Dielectric Capping Layers for High Efficiency Rear Passivated Silicon Solar Cells. In Proceedings of the 29th European Photovoltaic Solar Energy Conference and Exhibition (EU PVSEC), Amsterdam, The Netherlands, 22-26 September 2014; pp. 1337-1341.

47. Forniés, E.; Souto, A.; Vlasenko, T.; Pérez Vázquez, A.; Tojeiro, M.; Anoshenko, M. Performance of Modules and Solar Cells Made of 100\% Solar Silicon Purified by Direct Route. In Proceedings of the 35th European PV Solar Energy Conference and Exhibition (EU PVSEC), Brussels, Belgium, 24-28 September 2018; pp. 473-475.

48. Forniés, E.; Silva, J.P. Cell-to-module losses in standard crystalline PV modules-An industrial approach. Photovolt. Int. 2015, 29, 91-100.

49. Wang, Y.; Singh, J.P.; Sheng, Y.; Khoo, J.; Chai, Z.L. Cell-to-module power loss-gain analysis of silicon wafer-based PV modules. Photovolt. Int. 2016, 31, 90-98.

50. Hoffmann, V.; Zou, S.; Míguez, J.M.; Su, X. Enhancing Performance of Upgraded Metallurgical Grade Silicon Solar Cells Nano-Textured by Using Metal Catalyzed Chemical Etching. In Proceedings of the 33th European PV Solar Energy Conference and Exhibition (EU PVSEC), Amsterdam, The Netherlands, 25-29 September 2017; pp. 613-616.

51. Deng, W.; Chen, D.; Xiong, Z.; Verlinden, P.J.; Dong, J.; Ye, F.; Li, H.; Zhu, H.; Zhong, M.; Yang, Y.; et al. 20.8\% PERC Solar Cell on $156 \mathrm{~mm} \times 156 \mathrm{~mm}$ P-Type Multicrystalline Silicon Substrate. IEEE J. Photovolt. 2016, 6, 3-9. [CrossRef]

52. Sánchez, E.; Torreblanca, J.; Dieguez, J.; Ordás, R. Análisis comparativo de una instalación fotovoltaica de demostración de la tecnología de silicio de grado metalúrgico mejorado (UMG). In Proceedings of the XII Congreso Iberoamericano de Energía Solar, Madrid, Spain, 20-22 June 2018; pp. 1001-1007.

53. Ponce-Alcántara, S.; Connolly, J.P.; Sánchez, G.; Míguez, J.M.; Hoffmann, V.; Ordás, R. A Statistical Analysis of the Temperature Coefficients of Industrial Silicon Solar Cells. Energy Procedia 2014, 55, 578-588. [CrossRef]

(C) 2019 by the authors. Licensee MDPI, Basel, Switzerland. This article is an open access article distributed under the terms and conditions of the Creative Commons Attribution (CC BY) license (http://creativecommons.org/licenses/by/4.0/). 